DOI: $10.31393 /$ reports-vnmedical-2021-25(3)-28

UDC: $616.152 .72: 155.194 .8$

\title{
SCIENTIFIC REVIEWS. PRINCIPLES OF DIAGNOSIS AND TREATMENT OF IRON DEFICIENCY ANEMIA IN CHILDREN
}

Korol T. G., Khromykh K. V., Rudenko H. M., Bereznitskiy A. V.

National Pirogov Memorial Medical University, Vinnytsia (Pyrogov street, 56, Vinnytsia, Ukraine, 21018)

Responsible for correspondence: e-mail: tanya.korol.75@gmail.com

Received: July, 15, 2021; Accepted: August, 04, 2021

\begin{abstract}
Annotation. In Europe, the overall prevalence of iron deficiency anemia is 2-4\%, with two peaks: young children (2.3-15\%) and adolescents (3.5-13\% - in boys, 11-33\% - in girls). Iron deficiency occurs earlier than anemia, which is characterized by a decrease in the size and iron saturation of erythrocytes, and they become microcytic and hypochromic. Therefore, anemia can be prevented by early diagnosis and treatment of latent iron deficiency. The aim of the work was to analyze and systematize the main problematic issues of diagnosis and treatment of iron deficiency anemia in children. To conduct the study, we analyzed databases PubMed, Cochrane Library, Google Scholar, etc., referring to the vast majority of publications from the last five years (2016-2021), in addition to three articles published in 2012 and 2014. The main criteria for selecting sources were: the availability of the latest methods for the diagnosis of anemia, modern methods of treatment of iron deficiency anemia in children. Analysis of the identified literature sources showed that iron deficiency in the laboratory and clinically can manifest itself at different stages. Negative iron balance, which persists after a decrease in iron stores, is manifested by a decrease in hemoglobin and the development of anemia. A decrease in the number of erythrocytes or the level of hemoglobin $(\mathrm{Hb})$ by 5 percentile below the normal value of hemoglobin, determined for a given age in healthy people, is called anemia. Routine screening for iron deficiency should be performed in children aged 6 to 24 months. Screening consists of identifying risk factors and laboratory testing if available. Determination of serum ferritin during the first screening is the main diagnostic tool in children with risk factors for iron deficiency and signs of anemia. Ferritin levels should always be carefully evaluated, as ferritin is nonspecifically elevated in a variety of inflammatory conditions. Other screening tests, such as reticulocyte levels, iron transferrin saturation, and serum iron-binding capacity, are performed to confirm the diagnosis. The choice and route of administration of iron requires consideration of the cause that led to its deficiency, the severity of symptoms and condition of the patient, the probable and desired rate of hematological response, risks and complications of treatment, availability of resources and preferences of the patient. Oral iron remains a priority for the treatment of children with iron deficiency anemia, but it is necessary to consider situations where first-line therapy will be administered by intravenous means. Thus, based on the analysis of the literature, we can conclude that iron deficiency anemia remains an urgent medical and social problem today. Children with iron deficiency anemia develop cognitive impairment that does not fully recover even after treatment. Therefore, further research aimed at improving methods of prevention, early diagnosis and treatment of iron deficiency anemia in different age groups of children should be promising.

Keywords: iron deficiency, anemia, children.
\end{abstract}

\section{Introduction}

According to the WHO, about two-thirds of children and adolescents in countries with low social levels have iron deficiency. It is estimated that about $25 \%$ of preschool children suffer from iron deficiency anemia (IDA). In Africa, the prevalence of IDA among school-age children is quite high and still ranges from 64.3 to $71 \%$. In Europe, the overall prevalence is $2-4 \%$, with two peaks: young children (2.3$15 \%)$ and adolescents $(3.5-13 \%$ - in boys, $11-33 \%$ - in girls). In the United States, the prevalence of the disease is 1.6-7.4\% among children. Although the overall incidence of IDA has declined over the past decade, many surveys show that it remains relatively high among low-income families at $17 \%$ in children aged $1-2$ years and $6 \%$ in children aged 3-4 years [8]. Iron deficiency is a condition when the body's need for iron is not met and the balance of iron intake, reserves and losses of the body is insufficient to fully support the production of red blood cells. If left untreated, in $30 \%$ of cases, iron deficiency develops into IDA, which is the most common form of anemia in childhood [17]. Iron deficiency occurs earlier than anemia, which is characterized by a decrease in the size and iron saturation of erythrocytes, and they become microcytic and hypochromic. Therefore, anemia can be prevented by early diagnosis and treatment of latent iron deficiency [7].

The purpose of the work is to analyze and systematize the main problematic issues of diagnosis and treatment of IDA in children.

\section{Materials and methods}

To conduct the study, we analyzed databases PubMed, Cochrane Library, Google Scholar, etc., referring to the vast majority of publications from the last five years (2016 2021), in addition to three articles published in 2012 and 2014. The main criteria for selecting sources were: the availability of the latest methods for the diagnosis of anemia, modern methods of treatment of iron deficiency anemia in children.

\section{Results. Discussion}

In the early period of embryonic development, iron is necessary for the proper development of the brain with the proliferation, migration and differentiation of neuronal 
progenitor cells. This is due to the significant expression of transferrin receptors in the developing brain tissue. In further development, this process is limited to the cells of the blood-brain barrier and cerebrospinal fluid, which provides a constant supply of iron to the brain. It is believed that iron deficiency leads to a decrease in brain mass, which, in turn, disrupts the formation of myelin. Studies of infants who have suffered from iron deficiency during embryonic development reveal chronic and irreversible impairment of cognitive function, memory and motility, indicating a significant impact on the human brain [11].

Iron deficiency in the late embryonic period and in newborns also significantly affects brain development, causing cognitive impairment and emotional disturbances that can persist into adulthood despite normal iron levels. Potential mechanisms that contribute to these disorders include deficiency of brain energy metabolism, neurotransmission and myelination [5]. Iron is equally important for brain development in children of different ages. Deficiency of this trace element leads to long-term neurological disorders, including attention and memory deficits, mediated by the hippocampus and partly due to altered mitochondrial function and energy metabolism of neurons [6]. Iron deficiency without anemia often presents with persistent, unexplained, and nonspecific symptoms that are independent of the underlying disease. Symptoms of iron deficiency can occur due to metabolic processes, due to the fact that many proteins contain iron [18].

Iron deficiency in the laboratory and clinically can manifest itself at different stages. If the demand for iron is lower than consumption, the depot is emptied in the first place. At this time, the level of ferritin in plasma and iron saturation of plasma transferrin decreases. Negative iron balance, which persists after a decrease in iron stores, is manifested by a decrease in hemoglobin and the development of anemia. A decrease in the number of erythrocytes or the level of hemoglobin $(\mathrm{Hb})$ by 5 percentile below the normal value of hemoglobin, determined for a given age in healthy individuals, is called anemia [13].

The causes that lead to iron deficiency can be grouped into the following categories: inadequate food intake, increased body needs, decreased absorption, chronic inflammation and chronic blood loss. Absorption of iron occurs mainly in the stomach and proximal intestine under the influence of hydrochloric acid, which is necessary for the conversion of $\mathrm{Fe} \mathrm{3+}$ to $\mathrm{Fe} \mathrm{2+,} \mathrm{which} \mathrm{is} \mathrm{easier} \mathrm{to} \mathrm{digest}$ [1].

It is known that in the period of fetal development, this trace element comes from a pregnant woman to the fetus through the placenta. And in the last period of pregnancy, its total amount in the fetus is $75 \mathrm{mg} / \mathrm{kg}$. In the neonatal period, physiological anemia develops, but iron stores are sufficient to ensure erythropoiesis in the first 6 months of life, when there is no significant blood loss and do not require correction. In infants with low body weight and in infants with perinatal blood loss, stocks are depleted earlier.
Late umbilical cord compression may improve the situation and reduce the risk of iron deficiency [20].

It is proved that the iron content in breast milk is at its highest level in the first month of life, but it gradually decreases over time and in the fifth month is about $0.3 \mathrm{mg} /$ liter. In this case, the mother's diet does not affect the level of iron in breast milk. However, despite the fact that a baby with breast milk receives little iron, but its absorption is quite high - about $50 \%$. There are reports that the introduction of early feeding in the first 6 months of life, disrupts its absorption from breast milk. After all, the absorption is high, but still it is less than the needed for the growth of the baby. Thus, during the first 6 months of life, infants use iron from the depot until its supply of food increases [13].

The American Academy of Pediatrics recommends prescribing prophylactic iron at a dosage of $2 \mathrm{mg} / \mathrm{kg} /$ day to premature infants (born less than 37 weeks of gestation) who are exclusively breastfed, from 1 to 12 months, except for those who have been transfused repeatedly. erythrocytes. For full-term infants who are exclusively breastfed, start taking $1 \mathrm{mg} / \mathrm{kg} /$ day of elemental iron from four months of age before the introduction of appropriate products containing iron [21]. Infants under 12 months of age who are fed cow's milk rather than breast or ironfortified formulas are more likely to develop anemia. Cow's milk leads to anemia because: it contains less iron, causes minor blood loss from the intestine, impairs the body's absorption of iron [4].

There are several stages in the development of IDA, namely:

1. Preliminary stage (depletion of iron depo) characterized by depletion or absence of depot in combination with normal serum iron concentration, hemoglobin and hematocrit. This reduces the supply of iron in the bone marrow and reduces the level of ferritin in the serum.

2. Latent stage (violation of iron transport) - a characteristic feature of which is a decrease in iron saturation of transferrin, but the indicators of hemoglobin and hematocrit within the reference values.

3. Iron deficiency anemia (IDA) - is characterized by a decrease in iron in the depot, serum, low hemoglobin and hematocrit and the appearance of clinical symptoms [9].

Clinical symptoms of iron deficiency are characterized by signs of hypoxia of the brain and other body systems, which leads to the development of trophic changes in tissues and depend on the degree of anemia.

There are no symptoms in case of mild anemia. However, decreased iron and blood levels can cause irritability, restlessness, drowsiness, shortness of breath, tachycardia, loss of appetite and cravings for inedible substances, constant fatigue, headache or dizziness, and decreased attention and memory. With more severe anemia, pale skin, hemodynamic disorders, dullness and fragility of hair and nails may occur [16]. 
Routine screening for iron deficiency should be performed in children aged 6 to 24 months. Screening consists of identifying risk factors and laboratory testing if available. According to the recommendations of the American Pediatric Association, all children 9 to 12 months of age should have a general blood test to assess all major indicators. Determination of serum ferritin during the first screening is the main diagnostic tool in children with risk factors for iron deficiency and signs of anemia. Ferritin levels should always be carefully evaluated, as ferritin is nonspecifically elevated in a variety of inflammatory conditions. Other screening tests, such as reticulocyte levels, iron transferrin saturation, and serum iron-binding capacity, are performed to confirm the diagnosis [15].

Serum ferritin levels are considered a sensitive test to assess iron depot. Its concentration is less than $12 \mathrm{~g} / \mathrm{l}$ in favor of iron deficiency [23].

In order to correct iron deficiency, it is necessary to eliminate the cause and replenish its reserves. Elemental iron is a pharmacologically active component of oral iron supplements. In children with IDA, the standard therapeutic dose is $2-6 \mathrm{mg} / \mathrm{kg} /$ day of elemental iron for 3-6 months [14]. Because the daily dose range is significant, randomized trials have been conducted in some countries and it has been shown that treatment with low doses of oral iron can be as effective as high doses. In addition, in the groups with the lowest doses, the frequency of side effects was much lower [2].

Iron supplements are recommended to be taken between meals, avoiding the use of inhibitors of its absorption, such as dairy products, tea and coffee. Medicines that reduce stomach acidity, such as antacids, can also impair the absorption of oral iron, so they should be limited. It is better to take iron supplements together with vitamin C (orange juice or ascorbic acid), which improves the absorption of iron. Side effects of oral iron include nausea, constipation, diarrhea, vomiting, metallic taste in the mouth, dark stools, and in most cases they are

\section{References}

[1] Al-Naseem, A., Sallam, A., Choudhury, S., \& Thachil, J. (2021). Iron deficiency without anaemia: a diagnosis that matters. Clin Med (Lond), 21(2), 107-113. doi: 10.7861/clinmed.2020 0582

[2] Al Sulayyim, H. J., Al Omari, A., \& Badri, M. (2019). An assessment for diagnostic and therapeutic modalities for management of pediatric Iron defficiency Anemia in Saudi Arabia: a crossectional study. BMC Pediatr., 19, 314. https://doi.org/ 10.1186/s12887-019-1704-3

[3] Auerbach, M., \& Adamson, J. W. (2016). How we diagnose and treat iron deficiency anemia. Am J Hematol., 91(1), 31-8. doi: 10.1002/ajh.24201

[4] Baker, R. D., \& Baker, S. S. (2016). Infant and toddler nutrition In: Wyllie, R., Hyams, J. S., Kay, M. (eds). Pediatric Gastrointestinal and Liver Disease. (5th ed.). (chap. 85) Philadelphia, PA: Elsevier.

[5] Bastian, T. W., Rao, R., Tran, P. V., \& Georgieff, M. K. (2020) The Effects of Early-Life Iron Deficiency on Brain Energy Metabolism. Neurosci Insights. 15, 2633105520935104. doi: dose-dependent [19]. Oral iron preparations are usually used for treatment, but there are parenteral drugs that are recommended for children with intolerance to oral drugs, impaired absorption, after surgery on the stomach or intestines, chronic kidney disease [3]. In this case, intravenous iron is recognized as a first-line therapy that will meet the needs of the child's body. However, severe hypersensitivity reactions and serious side effects, including anaphylaxis, are rare, and their diagnosis and treatment are well described in the literature [10]. Hypophosphatemia is a recognized complication of intravenous iron administration and is more common with ironcarboxymaltose [22]. The choice and route of administration of iron requires consideration of the cause that led to its deficiency, the severity of symptoms and condition of the patient, the probable and desired rate of hematological response, risks and complications of treatment, availability of resources and preferences of the patient. Oral iron remains a priority for the treatment of children with iron deficiency anemia, but it is necessary to consider situations where first-line therapy will be carried out using intravenous drugs [12].

\section{Conclusions and prospects for further development}

1. Based on the analysis of the literature, we can conclude that iron deficiency anemia remains an urgent medical and social problem today.

2. More than $25 \%$ of the population suffers from iron deficiency, which leads to disruption of many physiological functions, namely: binding and transport of oxygen, cell growth and differentiation, gene regulation, enzymatic reactions and the synthesis of neurotransmitters.

3. Children with iron deficiency anemia develop cognitive impairment that does not fully recover even after treatment.

Further research should be aimed at improving methods of prevention, early diagnosis and treatment of iron deficiency anemia in different age groups of children.

$10.1177 / 2633105520935104$

[6] Bastian, T. W., von Hohenberg, W. C., Mickelson, D. J., Lanier, L. M., \& Georgieff, M. K. (2016). Iron Deficiency Impairs Developing Hippocampal Neuron Gene Expression, Energy Metabolism, and Dendrite Complexity. Dev Neurosci., 38(4), 264-276. doi: 10.1159/000448514

[7] Camaschella, C. (2017). New insights into iron deficiency and iron deficiency anemia. Blood Rev., 31, 225-33. 10.1016/ j.blre.2017.02.004

[8] Choudhury, V., Amin, S. B., Agarwal, A., Srivastava, L. M., Soni, A., \& Saluja, S. (2015). Latent iron deficiency at birth influences auditory neural maturation in late preterm and term infants. Am J Clin Nutr., 102(5), 1030-4. doi: 10.3945/ajcn.115.113084

[9] Lim Jae-Young (2014). Iron Deficiency Anemia In Infants And Young Children. Clinical Pediatric Hematology-Oncology, 21(2), 47-51.

[10] Lim, W., Afif, W., Knowles, S., Lim, G., Lin, Y., Mothersill, C., ... \& Xenodemetropoulos, T. (2019). Canadian expert consensus: management of hypersensitivity reactions to intravenous iron 
in adults. Vox Sang., 114(4), 363-373. doi: 10.1111/vox.12773

[11] Markova, V., Holm, C., Pinborg, A. B., Thomsen, L. L., \& Moos, T. (2019). Impairment of the Developing Human Brain in Iron Deficiency: Correlations to Findings in Experimental Animals and Prospects for Early Intervention Therapy. Pharmaceuticals (Basel), 12(3), 120. doi: 10.3390/ ph12030120

[12] Ning, Shuoyan, \& Zeller, Michelle P. (2019). Management of iron deficiency. Hematology Am Soc Hematol Educ Program, 2019(1), 315-322. doi: 10.1182/hematology.2019000034

[13] ?zdemir, N. (2015). Iron deficiency anemia from diagnosis to treatment in children. Turk Pediatri Ars., 50(1), 11-19. doi: 10.5152/tpa.2015.2337

[14] Ozsurekci, Y., Unal, S., Cetin, M., \& Gumruk, F. (2019). Comparison of ferrous sulfate, polymaltose complex and ironzinc in iron deficiency anemia. Minerva Pediatr., 71(5), 44954. doi: 10.23736/S0026-4946.17.04268-2

[15] Roganovic, J. \& Starinac, K. (February 7th 2018). Iron Deficiency Anemia in Children, Current Topics in Anemia. Jesmine Khan, IntechOpen, DOI: 10.5772/intechopen.69774

[16] Rothman, J. A. (2020). Iron-deficiency anemia. In: Kliegman, R. M., St. Geme, J. W., Blum, N. J., Shah, S. S., Tasker, R. C., \& Wilson, K. M., (eds). Nelson Textbook of Pediatrics. (21st ed.). (chap 482). Philadelphia, PA: Elsevier.

[17] Sezgin, G., Li, L., Westbrook, J., Wearne, E., Azar, D., McLeod, A., ... \& Monagle, P. (2021). Influence of serum iron test results on the diagnosis of iron deficiency in children: a retrospective observational study. BMJ Open., 11(7), e046865. doi:10.1136/ bmjopen-2020-046865

[18] Soppi, E. T. (2018). Iron deficiency without anemia - a clinical challenge. Clin Case Rep., 6(6), 1082-1086. doi: 10.1002/ ccr3.1529

[19] Tolkien, Z., Stecher, L., Mander, A. P., Pereira, D. I. A., \& Powell, J. J. (2015). Ferrous sulfate supplementation causes significant gastrointestinal side-effects in adults: a systematic review and meta-analysii. PLoS One, 10(2), e0117383. doi: 10.1371/journal.pone. 0117383

[20] van Rheenen, P. (2013). Less iron deficiency anaemia after delayed cord-clamping. Paediatr Int Child Health, 33(2), 578. doi: 10.1179/2046905513Y.0000000059

[21] Wang, M. (2016). Iron Deficiency and Other Types of Anemia in Infants and Children. Am Fam Physician, 93(4), 270-8. PMID: 26926814

[22] Wolf, M., Chertow, G. M., Macdougall, I. C., Kaper, R., Krop, J., \& Strauss, W. (2018). Randomized trial of intravenous ironinduced hypophosphatemia. JCI Insight., 3(23), 1-12. doi: 10.1172/jci.insight.124486

[23] Worwood, M. Indicators of the iron status of populations: ferritin. In: CDC WHO (ed.). (2007). Assessing the Iron Status of Populations: Report of a Joint World Health Organization/ Centers for Disease Control and Prevention Technical Consultation on the Assessment of Iron Status at the Population Level. (2nd ed.). (p. 35-74). Geneva: World Health Organization.

\section{НАУКОВІ ОГЛЯДИ. ПРИНЦИПИ ДІАГНОСТИКИ ТА ЛІКУВАННЯ ЗАЛІЗОДЕФІЦИТНОЇ АНЕМІЇ У ДІТЕЙ}

\section{Король Т. Г., Хромих К. В., Руденко Г. М., Березніцький О. В.}

Анотація. У Європі загальна поширеність залізодефріцитної анемії становить 2-4\%, з двома піками: діти молодшого віку (2,3-15\%) та підлітки (3,5-13\% - у хлопчиків, 11-33\% - у дівчаток). Дефіiцит заліза виникає раніше, ніж розвивається анемія, що супроводжується процесом зменшення розмірів і насичення залізом еритроцитів, при чому вони стають мікроцитарними та гіпохромними. Тому анемії можна запобігти за допомогою ранньої діагностики та лікування латентного дефріциту заліза. Метою роботи було проаналізувати та систематизувати основні проблемні питання діагностики та лікування залізодефіцитних анемій у дітей. Для проведення дослідження нами були проаналізовані бази даних PubMed, Cochrane Library, Google Scholar ma ін., посилаючись в переважній більшості на публікації останніх п'яти років (2016 - 2021), окрім трьох статей опублікованих у 2012 та 2014 роках. Основними критеріями відбору джерел були: наявність новітніх методик діагностики анемій, сучасні методи лікування залізодефріцитних анемій у дітей. Аналіз виявлених літературних джерел показав, що дефіцит заліза лабораторно і клінічно може проявлятися на різних стадіях. Негативний баланс заліза, який зберігається після зменшення запасів заліза, проявляється зниженням гемоглобіну та розвитком анемії. Зниження кількості еритроцитів або рівня гемоглобіну $(\mathrm{Hb})$ на 5 перцентиль нижче нормального значення гемоглобіну, визначеного для даного віку у здорових осіб, називається анемією. Рутинний скринінг на виявлення дефріциту заліза слід проводити у дітей віком від 6 до 24 місяців. Скринінг складається з визначення факторів ризику та лабораторного тестування при їх наявності. Визначення сироваткового феритину під час першого скринінгу є основним діагностичним інструментом у дітей з фракторами ризику дефріциту заліза та ознаками анемії. Рівні фреритину слід завжди ретельно оцінювати, оскільки фреритин неспецифрічно підвищується при найрізноманітніших запальних станах. Інші скринінгові тести, такі як визначення рівнів ретикулоцитів, насичення трансферину залізом, залізозв?язуючої здатності сироватки проводять з метою підтвердження діагнозу. Вибір та шлях введення препаратів заліза вимагає врахування причини, яка призвела до його дефріциту, важкості симптомів та стану пацієнта, вірогідної та бажаної швидкості гематологічної відповіді, ризиків та ускладнень лікування, наявності ресурсів та уподобань пацієнта. Пероральне залізо залишається пріоритетним для лікування дітей із залізодефріцитною анемією, однак необхідно враховувати ситуації, коли терапія першої лінії буде проходити за допомогою внутрішньовенних засобів. Таким чином, на основі проведеного аналізу літератури можна зробити висновок, що залізодефіцитна анемія залишається актуальною медико-соціальною проблемою сьогодення. У дітей із залізодефріцитною анемією виникають когнітивні порушення, які навіть після лікування не повністю відновлюються. Тому перспективними мають бути подальші дослідження, які спрямовані на удосконалення методів профрілактики, ранньої діагностики та лікування залізодефіцитної анемії в різних вікових групах дитячого населення.

Ключові слова: дефріцит заліза, анемія, дітu. 